\author{
Björn Sundmark \\ Malmö University
}

DOI: http://dx.doi.org/10.5617/adno.5642

\title{
The Visual, the Verbal, and the Very Young: A Metacognitive Approach to Picturebooks
}

\begin{abstract}
The article draws on recent research into emergent literacy and metacognition, and charts a developmental trajectory from early concept books to picturebooks aimed at children and young teenagers. Methodologically, the study is a research synthesis, where the aim is to systematize current research findings and offer an overview of different types of picturebooks, and how they build literary and metacognitive competence. My thesis is that picturebooks are crucial in that process. The analysis focuses on the metacognitive affordances that can be found in picturebooks directed at different age groups/competence levels. Both the verbal and visual dimensions of the text are analyzed with the help of picturebook and comic book theory (iconotext, sequentiality). The results show that early concept books are surprisingly abstract; they stimulate the child's aesthetic-affective response by using clear colours and easily discernible shapes. In the next stage, things (nouns) from the child's close environment are represented. Naming and identifying are crucial activities at this stage. Verboriented concept books follow; these typically focus on simple actions from the child's lifeworld, such as getting dressed, or eating. Next, we find narrative picturebooks, in which the fundamentals of story, plot, and characterization are introduced. Finally, the potential for advanced storytelling is explored with regard to symbolism, irony, and character development.
\end{abstract}

Keywords: picturebooks, early concept books, metacognition, iconotext, narrative picturebooks 


\section{Bilderbokens berättelser: Ett metakognitivt perspektiv på bilderböcker}

\section{Sammanfattning}

Den här artikeln bygger på nyare forskning om literacyutveckling och metacognition, och kartlägger utvecklingslinjer från tidiga begreppsböcker riktade till spädbarn till bilderböcker som vänder sig till barn och tonåringar. Metodologiskt är arbetet ett forskningssyntes, där målet är att systematisera forskningsrön, erbjuda en ålders- och/eller utvecklingsindelad bilderboksöversikt, samt påvisa hur dessa böcker kan bygga litterär och metakognitiv kompetens. Min tes är att bilderböcker spelar en avgörande roll $i$ den processen. Analysen sätter fokus på de metakognitiva meningserbjudanden som kan återfinnas i olika bilderböcker. Såväl bild och skrift analyseras med hjälp av bilderboks- och serieteori. Resultaten visar att tidiga begreppsböcker är förvånansvärt abstrakta; de syftar främst till at stimulera barnets estetiskaffektiva respons genom användande av klara primärfärger och tydliga kontraster. I nästa skede återges saker och ting (substantiv) från barnets närmiljö. Verb-orienterade bilderböcker följer; dessa visar framför allt aktiviteter som barnet kan känna igen, som att äta, klä sig, eller gå och lägga sig. I nästa steg återfinns berättande bilderböcker. Där hittar vi berättandets grundbegrepp såsom handling, karaktär, konflikt. Till sist, i de mest sofistikerade bilderböckerna hittar vi symbolik, ironi, fördjupad karaktärsteckning och komplex tematik.

Nyckelord: bilderböcker, begreppsböcker, metakognition, ikonotext, bilderboksnarrativ

\section{Introduction}

In Lewis Carroll's Alice in Wonderland the heroine asks "What's the use of a book without pictures and conversations?" In this article I am going to turn this question on its head and ask instead, "what is the use of a book with pictures and conversations"? The article draws on recent research into emergent literacy and metacognition in early concept picturebooks, particularly by Bettina Kümmerling-Meibauer (2011) in combination with more text-oriented studies (Nikolajeva and Scott, 2001; Sipe, 2001; Christensen, 2010). It charts, tentatively, a developmental trajectory from so called "early concept books" aimed at toddlers - to more complex and demanding picturebooks for children and teenagers. Methodologically, the study is a research synthesis, where the aim is to systematize current research findings and offer an overview of different 
types of picturebooks, and how they build literary, linguistic, and metacognitive competence. My thesis is that picturebooks - understood and defined as books where the verbal and visual content is of equal importance (Sipe, 1998; Nikolajeva \& Scott, 2001) - are crucial to that process. All subsequent reading, as well as our ability to understand and enjoy storytelling - and also, by extension, our ability to empathize and successfully engage in social activity may well hinge on this first decisive step towards literacy and metacognitive development.

Theoretically, the article employs a metacognitive framework (Nelson and Narens, 1990; Israel, 2005). Metacognition involves knowledge and understanding of one's own thinking (metacognitive knowledge), as well as the way in which we monitor and control our own cognitive processes (metacognitive regulation), for instance by re-reading a text, or slowing down the pace of reading to ensure comprehension. In other words, metacognition is not only the ability to verbalize your own thought processes, but has a wider application. To "understand" a picture, to recognize a shape, or to assemble discrete shapes into a figure, to identify a letter or a word or a sentence - a reader makes use of different metacognitive strategies. Similarly, understanding narrative, assessing character traits, visualizing setting, interpreting literary themes, grasping a story's message, drawing on one's understanding of genre and media conventions, are skills that depend on your metacognitive ability. To use Harvey and Goudvis's categorization, these regulative metacognitive aspects can be labelled, "tacit, aware, strategic, reflective" (2007, p. 25). They are complementary rather than developmental in nature, and should not be used simply, as a blueprint for how a reader develops from "novice" to "expert," to use Nikolajeva's terms (2014). Suffice to say that much of the metacognitive work described in the following is "silent" and largely non-verbalized. Even the act of choosing/preferring a particular picturebook is in itself a sign of metacognitive regulation.

Picturebooks have rarely been discussed in metacognitive terms, but Perry Nodelman's Words about Pictures from 1988 starts by questioning some common assumptions about picturebooks, and what it is a child reader may be able to appreciate (or not) in different kinds of picturebooks. Important as this is, however, Nodelman does not connect the development of different picturebook genres as a response to differing and developing cognitive needs. Instead, the connection is made by David Lewis in a later study (2001), when he makes the observation that the development of different kinds of picturebooks can be seen as a "response to the gradual emergence of children's understanding of books and reading" (Lewis., p. xv). Still, the consequence of Lewis's insight remains largely a theoretical possibility, and is not fully realized in the organization of the book. Another inspiration for the present article is Maria Nikolajeva's Reading for Learning: Cognitive Approaches to Children's Literature (2014). Whereas both Nodelman and Lewis approach the subject from a reader-response 
point of view, Nikolajeva (in this study) is firmly in the cognitive camp. She investigates how literature is constructed to "optimize reader engagement" (4), and give readers knowledge (of world, of others, of self, of ethics). However, Nikolajeva's main concern here is the knowledge content rather than the metacognitive work, and as the title indicates, the subject is children's literature as a whole rather than the picturebook. Finally, and as I have already indicated, Kümmerling-Meibauer's Emergent Literacy (2011) has influenced my thinking with regard to how picturebook literacy is acquired. My possible contribution in this research synthesis lies in the systematization of the metacognitive steps, or "cases," outlined in Emergent Literacy, and, moreover, in suggesting a further trajectory, which also takes into account text-oriented picturebook theory.

The motivation behind this is that part of the metacognitive challenge with picturebooks is that they have both visual and verbal content (Sipe, 1998). In fact, this is what defines a picturebook. Thus in order to read and understand a picturebook, or just a page from a picturebook, you must be able to decode two semiotic sign systems separately, as well as understand how these two systems relate to and influence each other. Conceptually this is called iconotext by picturebook scholars (Hallberg, 1982; Nikolajeva \& Scott, 2001). According to iconotext theory, the relationship between the visual and the verbal text can be expressed in three ways:

- The image can illustrate the verbal text (correspondence)

- The image can complement the verbal text (complementarity)

- The image can contradict the verbal text (contradiction)

In the first case, the picture visualizes the written text (and vice versa). Text and image strive to support and reinforce each other. Obviously, however, there can never be a one to one correspondence since these are semiotic sign systems expressed through different modalities. In the second instance, writing and visuals complement each other. In the third, irony or subversion is the result. Another concept that underpins all my analyses is "sequence." In "sequential art," to borrow Will Eisner's term (2008) each picture or panel should be interpreted in relation to those that precede and follow, rather than in isolation (Groensteen, 2007; Miller, 2009). Accordingly, the analysis of picturebooks should also pay attention to how artists weave together recurring visual motifs. By recognizing the picturebook as both iconotextual and sequential in nature it is also easier to detect how each picture relates to the foregoing while anticipating the following (see also Sipe, 2011; Birkeland \& Mjør, 2012). Thus a narrative movement is created. Each spread, each turn of the page creates a reading rhythm and direction, while the breaks in-between represent time lapses, from seconds to hours to days. Such ellipses create narrative time where the story can play out. 
I have grouped the picturebooks under the following headings: early concept books, narrative picturebooks, and complex picturebooks. Each of these categories are broad and pull in different directions, and necessarily this presentation can only cover certain aspects. It is also true to say that there is some overlap between these categories. The ambition is to analyze a few sample picturebooks under each heading and try to ascertain which metacognitive challenges and affordances they present to readers.

\section{Early Concept Books}

Early concept books are the very first picturebooks that children encounter, at about three months of age (Kümmerling-Meibauer, 2011). Early concept books, exemplified by Chez Picthall's Baby Sees-series, represent basic shapes and colour contrasts; they are highly abstract and non-figurative, and aim at stimulating the child's aesthetic-affective response and pave the way for cognitive work (Kümmerling-Meibauer, 2011). Simplification and abstraction makes it possible for the child to discern patterns and to build spatial and graphic concepts, and develop symbolic thinking. The reason why the level of abstraction is so high very often early concept books resemble concrete, “difficult," non-figurative art - is that the sense of perspective and color perception is not yet fully developed in the toddler. That is why, for instance, primary colours dominate the palette. As Annette Werner has shown, monochromatic colours without hues are easier to discern for small children, and carry higher aesthetic enjoyment than black and white

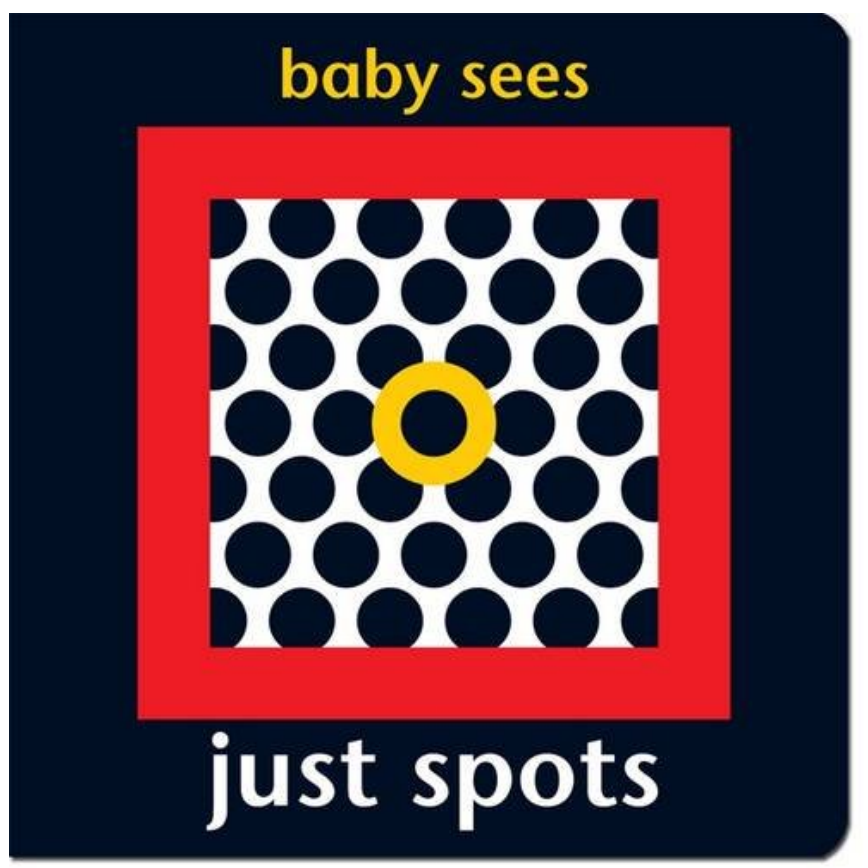
images, which may be surprisingly difficult to interpret and therefore tend to be rejected by children (2011).

In a later stage we find picturebooks that associate to things, rather than to shapes and forms and colours - objects that can be found in the child's surroundings, such as a lamp, a toy, or a spoon. This is yet another crucial step in the child's cognitive development. These are images that represent something real and identifiable, and points beyond itself. Thus, while colors and shapes are self-referential, a two-dimensional picture of a teddy bear becomes a sign that points beyond the child and the image of the toy; it represents a teddy bear, 
maybe the child's own cuddly toy. This realization is simple, yet fundamental. That pictures and words can signify something beyond themselves and beyond ourselves is a crucial and life-changing realization: stories, language, and communication depend on us understanding this. And it is a faculty that must be trained. A child who has grasped how signification/ representation works, and sees a circle on a page in a book, does not merely identify "roundness" or "circularity" (as in the Spots and Dots-books), but tries to figure out if the image represents a ball, a plate, a hole, or the sun etc. At this stage the focus is usually on identifiable objects (nouns), but also on some basic conceptual signs, such as letters (ABCs) and numbers. We can easily see how a circle also could stand for a zero or the letter "O." Combinations are not unusual either: a basic round shape that comes to represent both an orange and the letter " $\mathrm{O}$," for instance.

Early concept books contain a minimum of words, or are entirely wordless. The images represent identifiable objects (usually nouns) or basic conceptual signs, such as letters (ABCs) and numbers. When there is verbal content, the single words and short phrases complement the visual content. As a rule the verbal level works more as a support structure for a reading caretaker than for the child itself. Eventually, however, the child will decipher the writing as words, and connect them to the pictures. This is a crucial stage in the child's literacy development (and one that develops the child's capacity for symbolic thinking). One could say that the verbal aspect is present as a meaningful affordance, that the child can appreciate when it is ready for it.

Not that there is much to gain beyond simple signification (albeit a huge step in itself!) - the words are few and provide little by way of narrative enjoyment. The lack of characterization and storyline, however, is an adaptation to the cognitive level of the child. It is simply not meaningful to work with characters and plot development before the child can differentiate between itself and the exterior world, or before the child has developed a conventional time consciousness. Hence, in early concept books the child "reader" is in a sense the main character of the book.

More advanced lifeworld-oriented concept books may focus on toys or simple actions, such as getting dressed, or eating. The thematic cohesion could also be developed so that there is progression from one page to another. And instead of nouns and adjectives we find verbs expressing simple actions, such as getting dressed, preparing a meal, going to bed, or playing. Simple phrases accompany the images in these verb-focused concept books. We find things that belong, for instance to a toy animal, or clothes that a rabbit needs to go out and play. But the pictures are still highly stylized and the narrative content reduced to a minimum. There is no plot in these books. When reading an early concept book with a child a common approach is to name, show, point, look, and then turn to a new page. This pattern is often elaborated and given a question-andanswer-structure, for example: Q. What is this? A. It is... This "naming” process is accompanied by a growing ability to produce mental images of objects and 
concepts; it is a crucial step in children's emerging literacy, and metacognitive ablity. I will return to the development of narrative structure later, but I will first examine the picture conventions that are present in early concept books. My main example in this section will be from one of Dick Bruna's Miffy books; my analysis summarizes the main findings of Kümmerling-Meibauer (2011). Above is a typical picture from Miffy. The image appears to be simple, but in fact relies on a number of conventions that must be mastered before it will make sense. First of all, we note that "Miffy" is made up of discrete surfaces which are either white (head, hands, feet) or red (the dress), combined with dots (eyes), and a cross (nose). The figure is furthermore delineated against a blue background, and the different pictorial elements which make up Miffy are outlined by a black line so that each part is distinguished

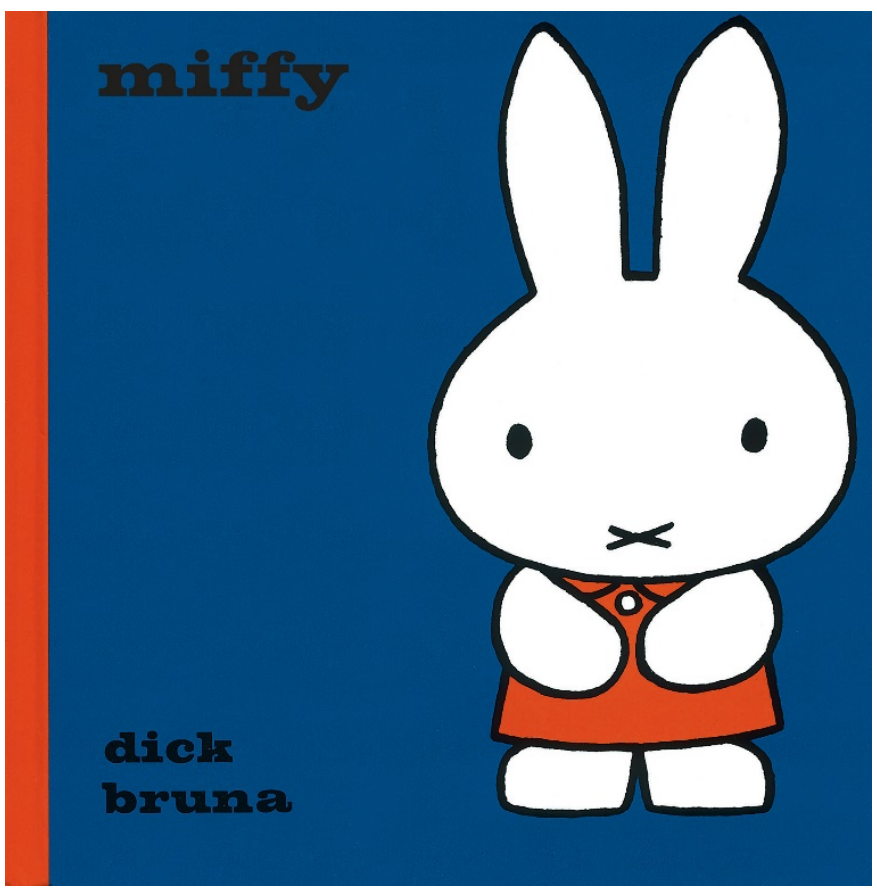
from the other parts, as well as from the background. Thus the reader will have to synthesize the different parts of Miffy and see them as constituting an indivisible object. One can add that the colours themselves are monochromatic (easy to discern but unrealistic - see discussion above). Second, Miffy herself has no natural connection to what could be called a natural environment. Instead she is suspended in "negative space," that is, in an unreal(istic) non-space. Thirdly, when reading the book one also notes that there is no (or reduced) proportionality. All objects and characters appear to be of roughly the same size regardless of their relative size, small things taking up as much space on the page as big things. Fourth, the dominating point of view is the en face, with the visual object represented as being at eye level with the audience/reader. Fifth, since there are no shadows, and no visible sources of light, the pictures are "flat." Obviously, pictures are always two-dimensional, but in early concept books, such as Miffy, all illusion of depth, perspective, proportionality, and three-dimensionality is reduced to a minimum. Add to that, six, that these are images of stasis. No movements are suggested through posture, figure placement, sequentiality, or the use of "speed lines." To be able to decode its meaning a child must be able to: 
- differentiate between figure and background

- recognize that lines, points and monochrome slabs of color are inseparable parts of a depicted object

- understand that two-dimensional pictures stand for three-dimensional objects

Thus, concept books like Miffy may appear "simple,” but are in fact highly abstract. They stimulate and require considerable development of the child's metacognitive capacity.

\section{Narrative picturebooks}

In later verb-focused picturebooks children are introduced to more sustained actions and to the idea of sequentiality. Actions and emotions - all central to narrative picturebooks - are of course conceptual too, but by using narrative as the defining trait we can see what is new at this stage in the child's metacognitive development. When focus is shifted from recognition and identification explored in early concept books to actions and activities, it can be warranted to explore Danish critic Nina Christensen's three-part categorization of picturebooks (2010) into minimal narrative picturebooks, dramatic narrative picturebooks, and person and conflict-oriented narrative picturebooks. A minimal narrative picturebook is a text where there is a protagonist whom the reader sees in different situations and where there is thematic cohesion (getting dressed, going to bed). At the same time there is virtually no plot development or dramatic conflict. The narrative is built on repetition of similar incidents; the structure is additive - first this, then that. The second category, minimal dramatic narrative picturebooks revolves around the chronological actions of a protagonist. This character has some agency but the level of involvement and affective response is low. The sequential aspect and logical progression are more worked through than in minimal narrative picturebooks. In practice it can be difficult to draw the line both between the first and second, and the second and third category. In theory, the third category puts more emphasis on how conflict affects the feelings and development of the central character. Broadly these are books that aim at children between two and six years of age (having said that, there will of course always be readers who are both younger and older who will appreciate these books). 
An interesting example of a minimal narrative picturebook can be found in Knacka på! [Knock! Knock!] by Anna-Clara Tidholm (1992). Here a dialogic form (question-answer-structure) is employed, the child is engaged physically, and is asked to identify different objects in the images, and to adopt the point of view of a child entering a house. Every other spread consists of a painted door (on the right) and the admonition to knock: "the red door / Knock! Knock!". On the following spread the reader encounters a room. The rooms are inhabited by one or more characters, "four monkeys," "seven rabbits," and are full of interesting things. Moreover, each room is associated with some form of activity, such as "monkey party," "beating a drum," "watering plants," "brushing teeth." Finally, each room has a door leading on to the next room. The book begins already on the cover where a child is seen from behind, about to knock on the door of a house. This is the only time we see the main character; in the rest of the book we share the point of view of the child. The narrative then takes us through the rooms of the house. Eventually the book ends when

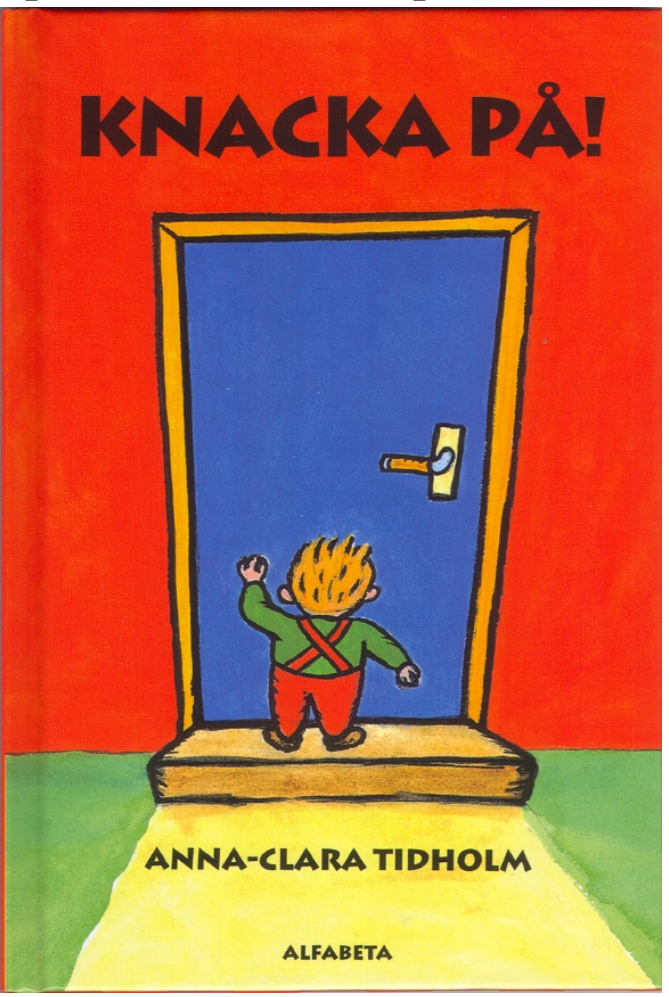
the reader exits the house, and night has fallen ("the moon is shining / we are outside again"). The structure of the story is compact, but the narrative development is slight. It is not the overall story that is important (getting through the house), nor the chronology (from daylight to nighttime). There is no apparent rising action in the different encounters or room-based activities. No, instead it has a lot in common with the concept books discussed earlier. It shows simple and well-known things from the child's life-world (nouns), a few activities signaled by verbs, as well as basic adjectives (colours), and numbers. The colours are strong and clear, without being comepletely monochromatic, as in Miffy. Contour lines are used, and the depicted characters and objects are simple, without being as abstract as in Miffy. There are no shadows, but the lighting differs over the page, and a few visible sources of light are shown (a lamp, the moon). The reader position is the same in all of the pictures, as if just entering the room. But in contrast to Miffy there are more details, and the objects are represented from different angles. As in Miffy the objects and characters are not in proportion to each other, but whereas the lack of proportionality is used to erase the sense of size difference in Miffy, it has the opposite function in Knacka på!, where attention is drawn to the difference in size between different things. There is also more suggested movement in the postures and activities in Knacka på! making the pictures more dynamic. As in the early concept books there is no 
main character to identify with (except on the cover); rather, the reader/viewer is the implied main character. Thus, although Knacka på! resembles concept books in several ways, there are also aspects that go well beyond what you would expect, and which makes it a minimal narrative picturebook. Importantly, the pictures complement and reinforce the text to a much greater extent than is common in concept books. For instance "the Little Old Man" is really minuscule both in relation to the towering plant that he is watering and the room he is in, with its great open spaces.

These tableaux do not just illustrate what is said in the text but complement the verbal text with things not named. The monkeys have a tree, and they have eight cushions in different colours and designs. And the illustrations also emphasise the fantastic or dreamlike quality of the story. Another, perhaps more correct way of describing the relationship between text and image in Knacka på! is to start with the visual, since it quite apparently is more important. Most of the meaning of Knacka på! is to be found on the visual level, after all. The words stitch together the content-rich images; they stitch the minimal narrative together; they provide structure. The repeated admonition to "knock" builds up the suspense and expectations, and the singling out of what is important in the rich images is essential for the sense-making and story-making. Each room is "read" in the same way, but every room is different. Through repetition and subtle variation Knock! Knock! achieves unity. The sequence of images and page turns also creates a sense of time. Something happens when you pass from one room to another. Instead of showing what plays out in each room by providing a succession of illustrations from each room, it is the spectator who keeps moving. Movement and narrative rhythm are marked by the spreads where the reader/viewer "knocks." The page turn marks the pulse of the picturebook story. It shows that time elapses and that something has happened/is happening. In Knacka på! this is accentuated further by the knock on the doorspreads. This increases the child's engagement in the act of reading. The knocking is performative and is what unlocks the next tableau. Figuratively, one could say that the book itself becomes a house of pictures and words that the child can open if it chooses to knock.

One can argue whether Knacka på! should be called a minimal narrative picturebook or be placed in Christensen's next category, the dramatic picturebook. Similarly, as my next example will show, it can also be difficult to draw the line between the dramatic picturebook and the third category, person and conflict-oriented narrative picturebooks. The main point, however, is that from a metacognitive point of view we can trace a development from early concept books without narrative, through books where narrative elements are introduced, to fairly complex stories and strong narratives.

Max nalle [Sam's Teddy Bear], by Barbro Lindgren (text) and Eva Eriksson (illustrations) (1981) is a good example of a picturebook which employs more advanced narrative techniques. Christensen places it in the third category, since 
character, conflict and plot development are important ingredients in it. Lindgren's and Eva Eriksson's books about Max/Sam are primarily aimed at children aged one to three. They share some features of simpler concept books and minimal narrative books, but contain elements which point to more advanced readings. The stories in the series relate simple storylines about things, places, emotions, and situations that the child can recognize. Unlike Miffy or Knacka på! they always have a simple but meaningful story to tell. In other words, there is more than thematic cohesion that binds the pages together - the pages follow the logic of narrative. On the pictorial level, the images are less abstract than those we find in Miffy, and less unrealistic than in Knacka på! The palette of colours is also different - not the monochromes of Miffy, nor the mixed primary colours of Knacka på! Instead the pages are painted in warm water colours with browns and yellows dominating. Even if the level of detail is reduced here too, to make it easier for the child to interpret the pictures, there are things to discover. The characters are also reproduced in a more realistic, expressive, and detailed way than what we find in the books discussed so far. Further, instead of using a neutral backdrop (negative space), as in Miffy, or a fantastic and dreamlike environment, as in Knacka på!, the characters are integrated in

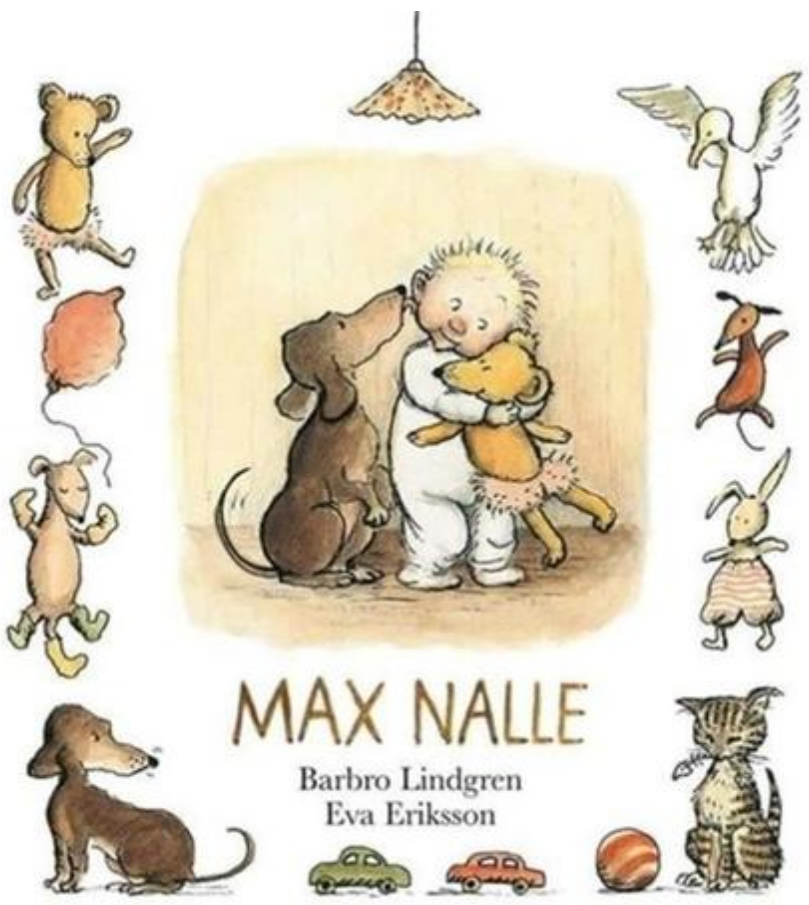
a natural and realistic setting.

Max is in his bed, in his room, on his potty, in a bathroom, or in the garden. The perspective and point of view is basically correct. Moreover, the relative proportions of characters and objects is stable and natural. There is suggested movement and dynamism in the images, as well as in between images. The latter is particularly interesting since the images in the previously discussed books can be characterized as stills of different disparate moments, the illustrations in the Sam books are more like snapshots taken in filmic flow.

In Max nalle the setting and scene are identical: Max's bed. The entire story plays out in it or in its immediate proximity. The perspective is fixed; all pictures are, as it were, taken from a point facing the bed. There are three characters: Max, vovve [dog], and nalle [teddy bear]. Beside the bed there are two other objects: a pair of slippers and the potty. One notes that the story fulfils the classic requirements (in drama) of unity of place and character. There is no 
jumping about between different locations, nor are new characters introduced as we go along. There is also unity of action and unity of time. In other words, we follow a story arc from start to finish, and the time it takes to tell the story corresponds with the time it would take for this action sequence to play out in reality. This simplicity and unity on the narratological level make it accessible to novice readers/listeners. The same stringence also applies to the language where only 38 words (in Swedish) are used for the whole book:
1.Look vovve
2.Look Max
3.Look nalle
4.Nalle is kind
5.Max kisses nalle
6.Max licks nalle
7.Max bites nalle
8.Max throws nalle
9.Nalle falls into potty
10.Nalle does not want to be in potty
11. Vovve helps
12.Vovve fetches nalle
13.Max gets nalle

Besides the names of the three characters - Max, nalle, and vovve (one or more of these three are mentioned in each phrase) - the text also contains one other noun, the potty, as well as one adjective "kind." The bed, the slippers, and a striped, blue and white blanket can be seen, but are not mentioned in the text. This makes the text strongly character and verb-driven: look (three times), kisses, licks, bites, throws, falls, wants, helps, fetches, gets. The verbal phrases are extremely simple, the most complex being the one where it says "Nalle does not want to be in potty." The illustrations underline the actions. There is a great deal of movement on the small stage, from the introductory game of peekaboo, to the climactic rescue operation. Vovve changes position and expression in each image. Nalle looks contented and relaxed when Max hugs it, but looks worried when thrown, and shakes its legs when stuck in the potty Max is the fixed centre; everyone and everything revolves around him.

The plot in Max nalle follows a classic pattern. First we have an initial situation, a harmonious status quo where the three characters are presented (pp. 1-4). This is followed by rising action, where Max shows how much he loves nalle (pp. 5-8). As a result of Max's excessive show of affection - his heroic fault, or hamartia to use the technical term - a crisis/complication occurs (the fall, pp. 9-10). In this situation Max is powerless, but as luck will have it, he has a helper in the form of vovve, who saves nalle (falling action, pp. 11-12). Finally, Max, nalle, and vovve are reunited (p. 13). Harmony is restored. 
Wordlessly, a parallel sub-plot is related as well, when vovve imitates Max's show of affection for nalle by licking and biting the slippers he finds under the bed. The images also reward the attentive reader by showing things not related in the verbal text. When Max, eyes closed, throws nalle, vovve has already interrupted his play to see what is happening. And nalle is looking worriedly towards the floor and the potty. Thus the reader can imagine what is about to happen before Max understands the consequences of his actions. The illustrations display distress, worry, relief and joy. There are many affective and expressive markers on the visual level, if not the verbal. This would seem to satisfy Christensen's definition of the third category of narrative picturebooks, showing emotional conflict. Max nalle goes from happiness and play, via regret and worry, to relief, thankfulness and renewed happiness.

To summarize, Lindgren's and Eriksson's book contains a minimal plot (and sub-plot!), which can be analyzed in terms of initial situation (status quo), rising action, climax, falling action, resolution and new status quo (narrative arc). It has characters with specific roles (protagonist/hero, helper, a nalle "bride"), and a well-defined setting (Max's bed and its immediate surrounding). There is emotional and affective content as well, as witnessed by tears and worried faces. To use Roland Barthes terminology this is "degree zero" literature - a complete story cannot be told in a simpler way. Max nalle has it all. World literature is really just variations and additions. If a child can enjoy Max nalle, it will be able to enjoy Shakespeare in due time.

\section{Complex Picturebooks}

There are only a few significant metacognitive hurdles left after Max nalle. And I am not referring to vocabulary or mastering more complex syntax, or foreign languages, which are all relatively easy in comparison to the interpretive and intellectual challenges involved when decoding early concept books, or understanding plot. More importantly, what we have not encountered so far in the discussed examples is sustained character development, nonlinear and convoluted storylines, thematic complexity and contradictory motivations, irony and subversion, and figurative language (metaphor, symbolism). It might be argued that the literary competence needed to appreciate complex picturebooks is beyond "the very young" signaled in the heading of this article. Age, however, is not an ideal indicator of literary competence, and the order in which picturebooks are read and appreciated can vary a great deal as well. In Cognitive Approaches to Children's Literature (2014), Maria Nikolajeva instead argues for the terms "novice reader" and "expert reader." I believe this is a fruitful approach, especially with regard to pre-teenagers, who can vary widely in reading habits and literary experience. One should also consider the crossover potential of picturebooks that may seem too complicated for a young reader. 
Picturebooks of high quality can appeal on many levels, and that which is beyond the grasp of a novice reader can still act as a stimulant for further reading if other aspects of the work are satisfying. A final reason for concluding this overview with complex picturebooks is that many of the aspects that are present in these picturebooks can be seen here and to a lesser extent in slightly less demanding picturebooks. But by focusing on, what are admittedly cuttingedge works, these traits are shown to greater effect.

In Shaun Tan's Rules of Summer (2013) the reader faces a much higher degree of complexity and ambiguity (for an in-depth analysis, see Kalogirou, 2017). The book consists of laconic "rules" on the left-hand side of the spreads, paired with rich and symbol-laden illustrations on the right. One of the first rules reads "Never leave a red sock on the clothesline." The accompanying image shows two boys huddled together behind a garden fence. In the small garden there is indeed a clothesline with a solitary red sock. A black bird regards them, and frighteningly, behind the boys on the other side of the fence there is an enormous red rabbit, perhaps looking for the two boys. What this means is not clear. Taken in isolation one can only assume that something bad happened during summer when a red sock was left on the clothesline, and that the two boys (brothers perhaps, rather than friends, judging by their different size/age) are somehow in it together. What the red rabbit represents is unclear, except that it is frightening.

When quickly browsing Rules of Summer one can get the impression that this is a simpler picturebook than Max nalle, and in terms of plot one would be partly right. Summer Rules is constructed more along the lines of Knacka på! Each spread represents a fascinating and slightly surrealistic tableau. The verbal text in both books is also simple and straightforward. But whereas the actions described in Knacka på! are innocent and incidental, the rules in Tan's book are inexplicable and mysterious. Only after having read the whole of Rules of Summer can one begin to puzzle together what may be the underlying plot, and the possible message of the story. But even then the images resist interpretation to a great extent. I will not attempt to analyze the book in any detail here, but one thing is clear: the relationship between the two boys develops over the course of the book; and the two characters, especially the smaller of the two (who also appears to be the focal character) is changed in the process. This is something we do not see in the earlier examples. Symbolism, not so much on the verbal level, is apparent in every full page illustration. One notes, for example, the black bird, which is present on every page except one. If a page were seen in isolation, the black bird might be overlooked as a mere detail, but after reading the whole book as a sequence one has to make the assumption that it is significant and does provide a key to the entire story. With Rules of Summer we have possibly come as far as is possible in terms of complexity. We have thematic development, use of visual metaphors and symbols, as well as complex themes. 
Finally, picturebooks, comics and graphic novels can work with longer time frames, make use of multiple characters, develop side-stories, and assume epic proportions, just like a novel, a film, an opera, or a TV series. In this respect the term "graphic novel" captures the novelistic and epic pretensions, not only the "graphic" (as in visual). An interesting example of a picturebook with such epic qualities is Legenden om Sally Jones by Jakob Wegelius (2008) ["The Legend of Sally Jones" - not translated into English]. This novel in pictures and words, set in the late $19^{\text {th }}$ century tells the epic story - told in 101 illustrations - of a gorilla named Sally Jones. She is caught by poachers, sold to a Turkish ivory trader in Léopoldville, and then has numerous adventures until she teams up with Koskela, or "the Chief," a Finnish sailor. Together they sail, eventually, into the sunset on the Congo river. In a sense, it is a Tarzan-in-reverse-story.

Where Tarzan is the human who becomes the king of the jungle through his strength and fighting skills, Sally

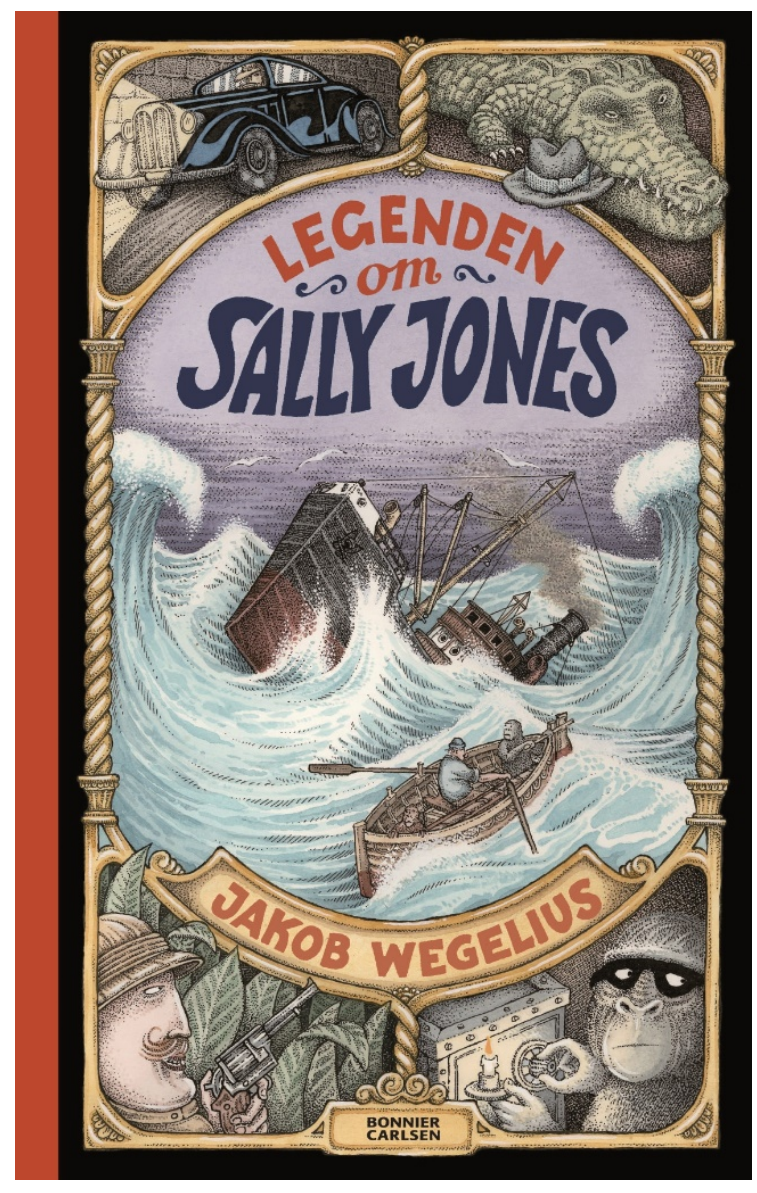
Jones is the animal who out-humans people with her personal qualities of loyalty, courage, perseverance, friendship, hard work, willingness to learn, and ingenuity. Legenden om Sally Jones resists easy definition. It is neither a proper comic book; there are for instance no panels, or strips, or word balloons. Nor is it sequential art as described by Will Eisner; seriality is not carried by image sequencing in this story, but rather by the words, the verbal narrative. A picturebook then? Perhaps, but it is too long and complex to easily fit that category either. Rather, it is a novel in pictures and words, or a graphic novel, but with the emphasis on novel. Legenden om Sally Jones may in some ways be less complex than Shaun Tan's Rules of Summer, but it demands other things of its readers. This is a long and convoluted story (with many side stories and digressions); it also portrays the adventurous life of one character, rather than just relating an episode or incident. It is full of human (well, gorilla) interest, and rewards the patient and observant reader. With Legenden om Sally Jones we have come a long way from Baby Sees Spots and Dots. 


\section{Conclusion}

This article charts, tentatively, a developmental trajectory from so called "early concept books" - aimed at toddlers - to more complex and demanding picturebooks for children and teenagers. Methodologically, the study is a research synthesis, where the aim is to systematize current research findings and offer an overview of different types of picturebooks, and how they build literary, linguistic, and metacognitive competence.

As I have shown in this review of picturebooks from the simplest (yet most abstract) to the most elaborate and complex, each category of picturebook requires new metacognitive skills. Another way of seeing it is that each category of picturebook exercises precisely those skills that the child needs, and hence enjoys using. It is the task of criticism and research to recognize those works that have the requisite qualities. In a small way, that is what I have endeavoured to do here. I have pursued the thesis that picturebooks are crucial in that process, and the analyses have focused on the metacognitive affordances that could be found in picturebooks at different levels of complexity. Both the verbal and visual dimensions of the text were analyzed with the help of picturebook and comic book theory. The results show that early concept books are surprisingly abstract; they stimulate the child's aesthetic-affective response by using clear colours and easily discernible shapes. Moreover, in the next stage, things (nouns) from the child's close environment are represented. Naming and identifying were noted as crucial activities at this stage. Verb-oriented concept books followed, typically centering on simple actions from the child's lifeworld, such as getting dressed, or eating. Next, we find narrative picturebooks, in which the fundamentals of story, plot, and characterization are introduced. Finally, the potential for advanced storytelling is explored with regard to symbolism, irony, and character development.

\section{About the author}

Björn Sundmark is Professor of English at Malmö University, Sweden, where he teaches and researches children's literature. Sundmark is the author of the monograph Alice in the Oral-Literary Continuum (Lund UP) and the editor (with Kit Kelen) of The Nation in Children's Literature (Routledge), and Where Children Rule: Child Autonomy and Child Governance in Children's Literature. He is the current editor of Bookbird: Journal of International Children's Literature.

Institutional affiliation: Department of Culture, Language and Media, Malmö University, 20506 Malmö, Sweden

E-mail: bjorn.sundmark@mah.se 


\section{References}

Birkeland, T. \& Mjør, I. (2012). Barnelitteratur: Sjangrar og teksttyper. 3rd ed. Oslo: Capelen Damm.

Bruna, D. (2003). Miffy. Glasgow: Egmont.

Christensen, N. (2010). Fiktion for begyndere: Narrativ forløb og karakterer i nordiske billedbøger for små børn. Barnelitteraert forskningstidsskrift, 1(1), 1-11.

Eisner, W. (2008). Comics and sequential art. New York: Norton.

Groensteen, T. (2007). The system of comics. Jackson: University of Mississippi.

Hallberg, K. (1982). Litteraturvetenskapen och bilderboksforskningen. Tidskrift för litteraturvetenskap, 3, 163-168.

Harvey, S. \& Goudvis, A. (2007). Strategies that work: Teaching comprehension for understanding and engagement. Maine: Stenhouse.

Israel, S. et al. (eds.) (2005). Metacognition in literacy learning: Theory, assessment, instruction, and professional development. Mahwah, N.J.: Erlbaum.

Kalogirou, T. (2017). Fracturing utopia/dislocating dystopia: A close reading of Rules of Summer by Shaun Tan. (eds.), Fractures and disruptions in children's literature. A. M. Ramos, S. Mourão, M. T. Cortez. Cambridge: Cambridge Scholars.

Kümmerling-Meibauer, B. (Ed.) (2011). Emergent literacy: Children's books from 0 to 3. Amsterdam: John Benjamins.

Lewis, D. (2001). Reading contemporary picturebooks: Picturing text. New York: Routledge.

Lindgren, B. \& Eriksson, E. (1981). Max nalle [Sam's Teddy Bear]. Stockholm: Rabén \& Sjögren.

Miller, A. (2009). Reading bande dessinée: Critical approaches to French-language comic strip. Bristol: Intellect.

Nelson, L. \& Narens, T. O. (1990). Metamemory: A theoretical framework and new findings. Psychology of Learning and Motivation, 26, 125-173.

Nikolajeva, M. \& Scott, C. (2001). How picturebooks work. New York: Garland.

Nikolajeva, M. (2014). Reading for learning: Cognitive approaches to children's literature. Amsterdam: John Benjamins.

Nodelman, P. (1988). Words about pictures. New York: Routledge.

Picthall, C. (2005). Baby sees spots and dots. Worksop: Award.

Sipe, L. (1998). How picture books work: A semiotically framed theory of text-picture relationships. Children's Literature in Education. 29(2), 97-108.

Sipe, L. (2011). The art of the picturebook, Eds. S. A. Wolf et al. (238-252), Handbook of research on children's and young adult literature. New York: Routledge.

Tan, S. (2013). Rules of summer. New York: Hodder.

Tidholm, A-C. (1992). Knacka på! [Knock! knock!]. Stockholm: Alfabeta.

Wegelius, J. (2008). Legenden om Sally Jones [The Legend of Sally Jones]. Stockholm: Bonnier.

Werner, A. (2011). Color perception in infants and young children: The significance of color in picturebooks, Emergent literacy: Children's books from 0 to 3. Ed. B. KümmerlingMeibauer, (pp. 39-54). Amsterdam: John Benjamins. 